\title{
Job Satisfaction of Pediatric Infectious Disease Physicians
}

\section{çocuk Enfeksiyon Hastalıkları Hekimlerinin Iş Doyumu}

\author{
Ayşe Büyükcam "1(īD) \\ ${ }^{1}$ Division of Pediatric Infectious Diseases, Department of Pediatrics, Hacettepe University School of Medicine, Ankara, Turkey
}

Cite this article as: Büyükcam A, Kara A. Job satisfaction of pediatric infectious disease physicians. J Pediatr Inf 2020;14(1):e9-e14.

\begin{abstract}
Objective: Job satisfaction is the degree of liking and satisfaction of employees. Job satisfaction, which is related to labor productivity and performance, increases the employee's commitment, motivation and adaptation to the workplace. Physicians can provide higher quality care when satisfied. Therefore, physician satisfaction is an important issue for both patients and health managers and physicians. It was aimed to investigate the levels of job satisfaction and the relationship between demographic characteristics, job characteristics and job satisfaction among pediatric infectious physicians in the present study.
\end{abstract}

Material and Methods: Out of 82 pediatric infections physicians in Turkey, this cross-sectional study was conducted with 62 physicians who agreed to participate in this questionnaire between 15 March and 6 April 2015 (response rate: 75\%). Minessota Satisfaction Questionnaire Short Form, a 5-point Likert-type scale consisting of 20 items and a questionnaire containing sociodemographic variables were used. SPSS 20.0 was used for data analysis.

Results: Mean age of the 62 pediatric infectious disease physicians was $38.9 \pm 8.4$ years, of whom $66.1 \%$ was females, $33.9 \%$ was males and $83.9 \%$ was married. Mean levels of participants were $71 \pm 10.3$ for general, $44.2 \pm 7.2$ for intrinsic and $25.8 \pm 5.7$ for extrinsic job satisfaction. There was a significant difference between age and intrinsic job satisfaction $(p=0.03)$. The lowest intrinsic satisfaction was found in the $30-40$ age group. Pediatric infection diseases physicians in university hospitals had a higher general job satisfaction ( $p=0.02$ ).

Conclusion: Pediatric infectious physicians had moderate job satisfaction and age and hospital level seem to be among the factors affecting job satisfaction. However, job satisfaction is a dynamic situation affected by many factors, and renewed and further studies are needed to reveal new valuable information.

Keywords: Job satisfaction, Minnesota job satisfaction scale, pediatric infectious disease physician
Öz

Giriş: Iş doyumu, çalışanların işlerini sevme ve memnuniyet derecesidir. İş doyumu, iş gücü verimliliği ve performansı ile ilgilidir. İş doyumu ile çaIışanın iş yerine karşı olan bağlılık, motivasyon ve uyumu artar. Hekimler memnun kaldığında hastalar daha iyi bir bakım alabilirler. Bu nedenle, hekim memnuniyeti hem hastalar, sağlık yöneticileri hem de hekimler için önemli bir konudur. Çalışmamızda çocuk enfeksiyon hastalıkları hekimleri arasındaki iş doyumu düzeyleri ile demografik ve iş özellikleriyle iş doyumu arasındaki ilişkinin araştırılması amaçlanmıştır.

Gereç ve Yöntemler: Bu kesitsel çalışma, 15 Mart 2015-6 Nisan 2015 tarihleri arasında Türkiye'de toplam 82 çocuk enfeksiyon hastalıkları hekiminden, bu anketi yapmayı kabul eden 62 hekim ile gerçekleştirildi (cevap oranı: \%75). Minessota İş Doyum Ölçeği kısa formu, 20 maddelik $5^{\prime}$ li Likert tipi bir ölçek ve sosyodemografik değişkenler içeren bir anket kullanıldı. Verilerin analizinde SPSS 20.0 kullanıldı.

Bulgular: Ankete katılan 62 çocuk enfeksiyon hastalıkları hekiminin yaş ortalaması $38.9 \pm 8.4$ yıl idi. Katılımcıların \%66.1'i kadın, \%33.9'u erkek; $\% 83.9^{\prime} u$ evli idi. Katılımcıların genel iş doyum düzeyleri $71 \pm 10.3$, içsel doyum $44.2 \pm 7.2$ ve dışsal doyum $25.8 \pm 5.7$ idi. Yaş ve içsel iş doyumu arasında anlamlı bir fark vardı $(p=0.038)$. En düşük içsel doyum 30-40 yaş grubunda idi. Üniversite hastanesinde çalışan çocuk enfeksiyon hastalıkları hekimlerinin daha yüksek bir genel iş doyumuna sahip oldukları tespit edilmiştir $(p=0.020)$.

Sonuç: Çocuk enfeksiyon hastalıkları hekimleri, orta düzeyde iş doyumuna sahiptir. Yaş ile hastane seviyesi iş doyumunu etkileyen faktörler arasında gibi görülmektedir. Bununla birlikte, iş doyumu birçok faktörden etkilenen dinamik bir durumdur ve yeni değerli bilgilerin ortaya konulabilmesi için yenilenen ve daha ileri çalışmalara ihtiyaç vardır.

Anahtar Kelimeler: İş doyumu, çocuk enfeksiyon hastalıkları hekimi, Minnesota iş doyum ölçeği 


\section{Introduction}

Job satisfaction is generally defined as the totality of perception or emotional responses regarding employment status (1). It is the people's degree of liking (statisfraction) or disliking (dissatisfaction) their jobs. When evaluated in general, job satisfaction is an attitudinal variable (1). Job satisfaction is related to workforce productivity and performance (2).

Healthcare institutions possess complex organizational systems and represent settings where staff from various professional groups co-operate and provide services constantly. Features of healthcare services vary and are distinctive; among these features are the series of activities that are manifold when compared to other service areas, higher number of problems faced when providing these services and their complex nature, higher expectations regarding outcomes, and the ability to obtain effective results medically (3). Physicians are healthcare workers trained to obtain history, perform thorough physical examinations, interpret laboratory and radiologic examinations, practice diagnostic and treatment methods, establish a diagnosis and commence a treatment (4). The mental health of physicians is in tendency to be protected with the increase in job satisfaction against the high necessities of medical practices (5). Modern medical workplace is a complex environment, and the responses given by physicians to this environment are highly varied (6). Provided that physicians are satisfied with their jobs and workplaces, patients can receive care at the highest quality. Therefore, physician satisfaction is a critical subject both for the patients and for healthcare management authorities and physicians themselves (3). There is a limited number of studies reporting job satisfaction rates of pediatric physicians in the literature; and besides, we could not find any study reporting job satisfaction rates of pediatric infectious diseases physicians $(2,3,6)$.

The aim of this study was to inquire the job satisfaction of pediatric infectious disease physicians and present the relation between job satisfaction rates and demographic features and job specifications.

\section{Materials and Methods}

This cross-sectional study was carried out by 62 physicians out of 82 pediatric infectious diseases physicians in Turkey that accepted to fill out the questionnaire between March 15 and April 6, 2015 (response rate: 75\%). The questionnaire was conducted face-to-face by the physicians who accepted to participate in the study. The questionnaire was divided into two parts as the Minnesota Job Satisfaction Scale short form (7) and sociodemographic variables. The questionnaire also included questions such as "Which preference (in order) was medical faculty in the university entrance examination?,
Would you prefer medical faculty again if you had the chance to retake the university entrance examination?, Would you prefer the sub-branch of pediatric infectious diseases if you had to choose again?, Would you like to be just a pediatrician at the present time?", and the form was filled out by the participants. The study was carried out in accordance with Good Clinical Practice and the Helsinki Declaration, and informed consent was received from all study participants.

\section{Minnesota Job Satisfaction Scale (MJSS)}

Minnesota Job Satisfaction Scale (MJSS) was developed in 1967 by Weiss, Dawis, England ve Lofquist (8). MJSS was translated into Turkish by Baycan in 1985, and its validity and reliability studies were performed (9). MJSS short form is a 5 -point Likert-type scale consisting of 20 items. MJSS comprises three sub-dimensions including intrinsic, extrinsic and general satisfaction. Intrinsic satisfaction covers factors like sense of success, promotion opportunities, productivity and working conditions. Extrinsic satisfaction covers factors like job security, wage and guidance opportunities. General satisfaction comprises factors regarding management and manager. Each item has five alternative responses that define a person's satisfaction degree including very dissatisfied, dissatisfied " $\mathrm{N}$ " (neither satisfied nor dissatisfied), satisfied and very satisfied. 1, 2, 3,4 , and 5 were given as scores respectively in the evaluation of these alternative responses. There are no reverse questions in the scale. Question items regarding intrinsic, extrinsic and general satisfaction of MJSS are:

1. Intrinsic satisfaction: 1, 2, 3, 4, 7, 8, 9, 10, 11, 15, 16, 20

2. Extrinsic satisfaction: 5, 6, 12, 13, 14, 17, 18, 19

3. General satisfaction: $1,2,3,4,5,6,7,8,9,10,11,12,13,14$, 15, 16, 17, 18, 19, 20.

Scores of general satisfaction, intrinsic satisfaction and extrinsic satisfaction are directly proportional to the degree of job satisfaction. Intrinsic satisfaction score is calculated by dividing the total score of the 12 items into 12 and extrinsic satisfaction score is calculated by dividing the total score of the 8 items into 8 . The highest score to be received from the scale is 100 and the lowest is 20 . If the scores are close to 20 , it means that the job satisfaction level is low and if the scores are close to 100, it means that the job satisfaction level is high $(7,10,11)$. Percentage values of job satisfaction level are classified as follows: 0-25 low, 26-74 moderate, 75-100 high (11).

\section{Analysis Methods}

The data were analyzed using SPSS Statistics 20.0 (SPSS, Chicago, IL, USA). Descrptive statistics are used to summarize the basic features of the participant. Mean value for continuous variables and frequency distribution and percentages were calculated for participant features. Cronbach alpha analysis was carried out to determine internal consistency. De- 
scriptive statistics, Mann-Whitney-U, Pearson Chi-square, Chisquare, Kruskal-Wallis, and Conover-Dunn tests were used for statistical analyses. Statistical significance was set at $p<0.05$ in the study.

\section{Results}

Mean age of the 62 pediatric infectious diseases physicians participating in the questionnaire was $38.9 \pm 8.4$ years. $66.1 \%$ of the participants were females, $33.9 \%$ were males, and $83.9 \%$ were married (Table 1 ). The participants responded to the question "Which preference (in order) was medical faculty in the university entrance examination?" as follows: $70 \%$ $(n=43) 1^{\text {st }}$ preference, $8 \%(n=5) 2^{\text {nd }}$ preference and $6 \%(n=$ 4) 3rd preference. $72 \%(n=44)$ responded 'yes' and $28 \%(n=$ 17) responded 'no' to the question: "Would you prefer medical faculty again if you had the chance to retake the university entrance examination?" $(n=61)$. There was an $88 \%(n=53)$ 'yes' response and $12 \%(n=7)$ 'no' response to the question: "Would you prefer the sub-branch of pediatric infectious diseases if you had to choose again?" $(n=62)$. When asked "Would you like to be just a pediatrician at the present time?" $(n=61)$, $16.1 \%(n=10)$ responded 'yes' and $83.6 \%(n=51)$ responded 'no'. It is expected from each factor to have a Cronbach alpha value of at least 0.70 for the reliability of data. In this study, intrinsic satisfaction, extrinsic satisfaction and general satisfaction had a Cronbach alpha value of $0.865,0.775$ and 0.827 , respectively. Moreover, mean score value and standard deviation of the responses given to each item are given in Table 2 .

Table 1. Demographic features of the participants

\begin{tabular}{|l|c|}
\hline Age (mean $\mathbf{\pm}$ SD) & $38.9 \pm 8.4$ \\
\hline $\begin{array}{l}\text { Sex, } \mathbf{n}(\%) \\
\text { Male }\end{array}$ & $21(33.9 \%)$ \\
$\quad$ Female & $41(66.1 \%)$ \\
\hline Marital status, $\mathbf{n}(\%)$ & $52(83.9 \%)$ \\
$\quad$ Married & $10(16.1 \%)$ \\
$\quad$ Single & \\
\hline Hospital, $\mathbf{n}$ (\%) & $41(66.1 \%)$ \\
University hospital & $16(25.8 \%)$ \\
Training and research hospital & $3(4.8 \%)$ \\
State hospital & $1(1.6 \%)$ \\
Private hospital & $36(58.1 \%)$ \\
\hline Sub branch resident now, $\mathbf{n}$ (\%) & $26(41.9 \%)$ \\
No & \\
Yes & - \\
\hline Working year*, $\mathbf{n}$ (\%) & $25(40.3 \%)$ \\
$<5$ & $36(58.1 \%)$ \\
\hline $5-10$ & \\
\hline$>10$ & \\
\hline${ }^{*}$ After completion of medical faculty. & \\
\hline
\end{tabular}

Table 2. Content, mean and standard deviation of the items

\begin{tabular}{|c|c|c|c|}
\hline MJSS & Career satisfaction status & Mean & Standard deviation \\
\hline MQ-1 & Being able to keep busy all the time & 3.0400 & 1.22824 \\
\hline MQ-2 & The chance to work alone on the job & 3.6600 & 0.89466 \\
\hline MQ-3 & The chance to do different things from time to time & 3.5600 & 1.03332 \\
\hline MQ-4 & The chance to be "somebody" in the community & 3.8800 & 0.68928 \\
\hline MQ-5 & The way my boss handles his/her workers & 3.1000 & 1.19949 \\
\hline MQ-6 & The competence of my supervisor in making decisions & 3.1800 & 1.30447 \\
\hline MQ-7 & Being able to do things that don't go against my conscience & 3.5400 & 1.01439 \\
\hline MQ-8 & The way my job provides for steady employment & 3.3200 & 1.07741 \\
\hline MQ-9 & The chance to do things for other people & 4.2600 & 0.69429 \\
\hline MQ-10 & The chance to tell people what to do & 4.0200 & 0.82040 \\
\hline MQ-11 & The chance to do something that makes use of my abilities & 4.0000 & 0.78246 \\
\hline MQ-12 & The way company policies are put into practice & 3.6200 & 0.92339 \\
\hline MQ-13 & My pay and the amount of work I do & 2.0800 & 1.02698 \\
\hline MQ-14 & The chances for advancement on this job & 3.6200 & 0.98747 \\
\hline MQ-15 & The freedom to use my own judgment & 3.6200 & 0.87808 \\
\hline MQ-16 & The chance to try my own methods of doing the job & 3.6200 & 0.87808 \\
\hline MQ-17 & The working conditions & 3.3600 & 1.10213 \\
\hline MQ-18 & The way my co-workers get along with each other & 3.7000 & 1.05463 \\
\hline MQ-19 & The praise I get for doing a good job & 3.3800 & 1.06694 \\
\hline MQ-20 & The feeling of accomplishment I get from the job & 3.8600 & 0.85738 \\
\hline
\end{tabular}


Table 3. Job satisfaction of pediatric infectious diseases physicians

\begin{tabular}{|l|c|c|}
\hline Job satisfaction & Mean & Standard deviation \\
\hline Intrinsic satisfaction & 44.2 & \pm 7.2 \\
\hline Extrinsic satisfaction & 25.8 & \pm 5.7 \\
\hline General satisfaction & 71 & \pm 10.3 \\
\hline \multicolumn{2}{|l}{} \\
\hline
\end{tabular}

General job satisfaction level, intrinsic satisfaction and extrinsic satisfaction of the participants were $71 \pm 10.3,44.2 \pm$ 7.2 and $25.8 \pm 5.7$, respectively (Table 3 ). Job satisfaction of pediatric infectious diseases physicians was moderate. Although there was not a statistical difference in terms of sex, general job satisfaction scores of males were 5.6 scores higher than those of females (male mean score: $74.7 \pm 10.3$, female mean score: $69.1 \pm 9.97$ ). There was a statistically significant difference between age and intrinsic satisfaction $(p=0.038)$. The lowest intrinsic satisfaction was found in the 30-40 age group. In addition, a significant relationship was determined between the level of hospital and general job satisfaction ( $p=$ 0.020). Pediatric infectious diseases physicians working in university hospitals had a much higher general job satisfaction rate. Moreover, extrinsic job satisfaction was higher in university hospital scores compared to state hospitals $(p=0.048)$.

\section{Discussion}

Job satisfaction is a sign of how much an employee is happy with his/her job (12). Moral and material satisfaction of a person from his/her job determines the well-being of his/ her mental and physical health. Job satisfaction is affected by personal factors such as personality, moral values, beliefs, expectations, socio-cultural setting, experience, age, education level, and intellect and by job-related factors including the difficulty and nature of work, wage, and promotion opportunities (13).

Dissatisfaction has been observed to bring along behavioral and emotional outcomes like carelessness, logginess, stress, depression, and fatigue and result in a decrease in organizational devotion at workplace and satisfaction in life, resignation, and application to early retirement (3). Employees that have reached a certain level of job satisfaction possess a higher morale and as a result, their service and benefit to the workplace increase. Moreover, devotion, motivation and harmonization of the employee towards his/her workplace is heightened with job satisfaction (13).

Job satisfaction in terms of job attitude has been extensively searched in organizational behavior literature (3). There are many theories conceptualized oriented at examining job satisfaction. These theories have been evaluated according to motivation and performance relations. Theories aimed at mo- tivation and job satisfaction are referred to as content theories, and theories aimed at performance and job satisfaction are referred to as expectation theories. In Hertzberg's double factor theory, which is an effective job satisfaction theory among all, features regarding job satisfaction and dissatisfaction including progress, recognition, the job itself, success, growth, and responsibility have been designated. Double Factor Theory of Hertzberg focuses on factors responsible for job satisfaction and dissatisfaction (14-16). Apart from this, there are various theories like the versatile and individual-specific Locke's Value Theory advocating the thought that the larger the value given to every factor, the more satisfactory changes can be produced and the Job Characteristic Model that has been formed to define task features and that generates a dominant framework to determine the relation between the employees and their motivation, performance and satisfaction $(17,18)$.

In recent years, researchers have started indicating that personal features (biographic factors) can be important while examining job satisfaction. Employees with the same job and similar working conditions may possess different job satisfaction levels (19).

One of the biggest challenges in assessing job satisfaction is that it is possible to be satisfied with several aspects of the job and not be satisfied with others at the same time (20). The literature has adopted two main approaches to scale job satisfaction: a general job satisfaction scale or scaling of various aspects of job satisfaction. Fist approach addresses general viewpoint and asks about general feelings related directly to the job, and the second approach emphasizes different aspects of the job (7). Numerous scales have been developed to inquire job satisfaction. Minnesota Job Satisfaction Scale (MJSS) is a well-known and validated scale studied widely. The reason for us in choosing this scale in our study was that it had received excellent alpha factor values (range: $0.85-0.91$ ) in previous studies (10) and its validity and reliability studies had already been performed in Turkish (9).

Job satisfaction carries grave importance in professions directly affecting non-professional lives and necessitating constant self-devotion (21). Jobs satisfaction research in healthcare services is carried out separately in professions like nurses and physicians. Therefore, it is seen that there is not a universal approach to healthcare services in hospitals that are important parts of the healthcare service of all employees (7). Nonetheless, there are many job satisfaction definitions in healthcare services similar to all literature. According to Stamps, job satisfaction is defined as the level of liking the job by employees $(22,23)$. Stahl, on the other hand, has defined job satisfaction as a person's feeling towards his/her jobs (24).

Job satisfaction is crucial for healthcare institutions. In this respect, job satisfaction of the physicians has vital importance 
since they are one of the significant production factors of a healthcare institution (3). When considered in terms of individuals working in healthcare, it is evident that job satisfaction is more important due to the fact that healthcare services focus on humans and necessitate constant attention and work (13). It has been pointed out that physicians dissatisfied with their profession go through an increase in health problems and burnout, prescribe risky medicine, have more dissatisfied patients and are more inclined to leave the profession. When the physicians are satisfied, the patients do not only receive sustainable care but also a higher quality of care. Thus, physician satisfaction is a critical subject for the patient and for the healthcare managers and physicians themselves (3). Since healthcare services contain people-oriented, labor-consuming activities, it is possible to state that the attitude and behavior of the employees play a vital role in providing efficient and high-quality healthcare services. In other words, the attitudes of the employees in healthcare institutions have a determinative role on healthcare services. Hence, decision-makers and management authorities should continuously monitor "organizational behavior" of their healthcare workers and develop new measures (3).

In general, choice of specialty, employment type and workplace satisfaction are significant factors for physician satisfaction (25). There are various studies in the literature showing the relation between specialty and job satisfaction. It has been demonstrated that since Surgical Sciences have higher workload and risky and stressful working environment compared to Internal Medicine, job satisfaction of the physicians in Surgical Sciences is lower $(26,27)$. In a study by Leigh et al. (28) regarding career satisfaction in 6590 physicians, satisfaction rate has been found high in pediatrics and sub branches of pediatrics. The reasons for this have been stated as follows: children tend to be more cheerful than adults, many health problems can be easily solved in children and thus physicians feel efficient, adults who choose to work with children are themselves more cheerful and pediatricians are faced with less "job stress". Nevertheless, in another study by Shugerman et al. conducted on 5704 physicians, it has been reported that compared to general pediatricians, specialists of sub-branches of pediatrics have a higher level of burnout and job stress ( $23 \%$ and $26 \%$ ) due to the fact that they work longer hours in hospital and encounter patients with complex medical and psychosocial problems (29).

Several studies have been conducted to inquire into and compare job satisfaction levels of male and female physicians. In our study, although job satisfaction was better in male physicians, there was not a significant difference between the sexes. Similarly, in the literature, many studies have not found a difference regarding job satisfaction in male and female physicians; however, there are few studies demonstrating sexwise differences in job satisfaction (25). Evaluating biographical features of the participants would be fitting on this matter.

Career satisfaction is naturally important in job satisfaction of the physicians. Physicians go through different challenges in different phases of their career. Although many are satisfied with their careers, the study by Dyrebye et al. (30) has put forth that there is a U-shaped relation between age and career satisfaction. While young and old physicians have been shown to have the highest career satisfaction, physicians in the midst of their careers have been shown to have the lowest satisfaction levels. Physicians in the midst of their career have been demonstrated to be in a difficult career phase together with higher career dissatisfaction no matter the specialty, setting and sex due to high work labor and higher burnout prevalence (30). Intrinsic satisfaction in MJSS comprises factors regarding satisfaction of the intrinsic quality of the job such as, success, recognition or appreciation, progression or promotion (31). The fact that intrinsic satisfaction shows differences with age has also been shown by the study of Dyrebye et al. (30) brings into mind the dissatisfaction and challenges he physicians in the midst of their career go through.

In our study, pediatric infectious diseases physicians working in university hospitals possessed a higher general job satisfaction rate. Moreover, extrinsic job satisfaction score in university hospital scores was higher than that of the state hospitals. Extrinsic satisfaction in MJSS comprises factors of the working environment such as management policy and administration, form of supervision, administrator, relations with subordinates and work, working conditions, and wage (31), and these factors affect job satisfaction. Although there are differences in several factors between university and other hospitals such as patient number, working conditions, and possibilities to progress and improve academically, there is a need for larger studies to generalize these differences in job satisfaction.

In conclusion, this study is a pioneering one in demonstrating job satisfaction of pediatric infectious diseases physicians in Turkey and putting forth its relation with demographic features and employment status. Pediatric infectious diseases physicians had a moderate job satisfaction, and age and level of hospital were among the factors affecting job satisfaction. Nevertheless, job satisfaction is a dynamic condition affected by many factors, and further studies are needed. Thus, a better physician satisfaction and healthcare service be provided by contributing to the elevation of job satisfaction of pediatric infectious diseases physicians who are vital for our country. 
Ethics Committe Approval: The study was conducted according to Good Clinical Practice and the Declaration of Helsinki.

Informed Consent: Patient concent was obtained.

Peer-review: Externally peer-reviewed.

Author Contributions: Concept - $A B, A K$; Design - $A B, A K$; Supervision - $A B, A K$; Materials - $A B, A K$; Data Collection and/or Processing - $A B$, $A K$; Analysis and/or Interpretation - $A B, A K$; Literature Review - $A B$, $A K$; Writing - $A B, A K$; Critical Review - $A B, A K$.

Conflict of Interest: No conflict of interest was declared by the authors.

Financial Disclosure: The authors declared that this study has received no financial support.

\section{References}

1. Spector PE. Job satisfaction: application, assessment, causes, and consequences. $1^{\text {st }}$ ed. 1997. [CrossRef]

2. Buchbinder SB, Wilson M, Melick CF, Powe NR. Primary care physician job satisfaction and turnover. Am J Manag Care 2001;7(7):701-13. [CrossRef]

3. Celen O, Teke A, Cihangiroglu N. The effect of socio-cultural characteristics on the effectiveness of teamwork: a study in the Gulhane Military

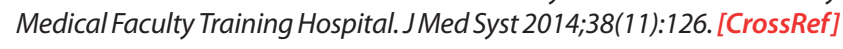

4. Ritsema TS, Roberts KA. Job satisfaction among British physician associates. Clin Med (Lond) 2016;16(6):511-3. [C Cross Ref ] ",

5. Ramirez AJ, Graham J, Richards MA, Cull A, Gregory WM. Mental health of hospital consultants: the effects of stress and satisfaction at work. Lancet 1996;347(9003):724-8. ['Crossief $]_{1}$

6. Ozyurt A, Hayran O, Sur H. Predictors of burnout and job satisfaction among Turkish physicians. QJM 2006;99(3):161-9. [C C

7. Martins H, Proença T. Minnesota Satisfaction Questionnaire-Psychometric properties and validation in a population of Portuguese hospital workers. FEP Journal-Economics \& Management: Working Paper 2012;471(1):1-23. [" [Cross Ref $]_{\mid}^{1}$

8. Weiss DJ, Dawis RV, England GW, Lofquist LH. Construct validation studies of the Minnesota Importance Questionnaire. Minnesota Studies in Vocational Rehabilitation, 1964. [CrossRef]

9. Baycan A. An analysis of the several aspects of job satisfaction between different occupational groups,Boğaziçi Üniversitesi SBE Doktora Tezi, istanbul, 1985. [CrossRef]

10. Fields DL. Taking the measure of work: a guide to validated scales for organizational research and diagnosis. Sage Publications, 2002. [CrossRef]

11. Akpınar A, Taş Y. Acil servis çalışanlarının tükenmişlik ile iş doyum düzeyleri arasındaki ilişkiyi belirlemeye yönelik bir araştırma. Türkiye Acil Tıp Dergisi 2011;11(4):161-5. [CrossRef]

12. Vieira JAC. Skill mismatches and job satisfaction. Economics Letters 2005;89(1):39-47. ['Cross Ref $]_{\|}$
13. Demir S. Ankara Üniversitesi Tıp Fakültesi Hastaneleri çalışanlarının tükenmişlik ve iş doyumu düzeylerinin bazı değişkenler açısından incelenmesi, 2013. [CrossRef]

14. Mullins LJ. Management and organisational behaviour: Pearson education, 2007. [CrossRef]

15. Maniram R. An investigation into the factors affecting job satisfaction at the KwaZulu Natal Further Education and Training College-Swinton Campus 2007. [CrossRef]

16. Köroğlu Ö. İçsel ve dışsal iş doyum düzeyleri ile genel iş doyum düzeyi arasındaki ilişkinin belirlenmesi: turist rehberleri üzerinde bir araştırma, 2012. [CrossRef]

17. Robbins SP. Organisational behaviour: concepts, controversies and applications Australia and New Zealand. Prentice Hall, 2001. [CrossRef]

18. Locke EA. The nature and causes of job satisfaction. Handbook of industrial and organizational psychology. Chicago: RandMc Narlly, 1976. [CrossRef]

19. Curtis EA, Glacken M. Job satisfaction among public health nurses: a national survey. J Nurs Manag 2014;22(5):653-63. [Cross Reef $]_{1}^{\prime}$

20. Spagnoli P, Caetano A, Santos SC. Satisfaction with job aspects: do patterns change over time? J Bus Res 2012;65(5):609-16. "[C [ross Ref $]_{1}$

21. Dağdeviren N, Musaoğlu Z, Ömürlü iK, Öztora S. Akademisyenlerde iş doyumunu etkileyen faktörler. Balkan Med J 2011;2011(1):69-74. [CrossRef]

22. Stamps PL, Piedmonte EB. Nurses and work satisfaction: an index for measurement. Health Administration Press, 1986. [CrossRef]

23. Castaneda GA, Scanlan JM. Job satisfaction in nursing: a concept analysis. Nurs For 2014;49(2):130-8. "[CrossRef $]_{1}$

24. Stahl MJ. Encyclopedia of health care management. Sage Publications, 2003. [CrossRef]

25. Van Ham I, Verhoeven AA, Groenier KH, Groothoff JW, De Haan J. Job satisfaction among general practitioners: a systematic literature review. Eur J Gen Pract 2006;12(4):174-80. ['Cross Ref] $]_{1}$

26. Freeborn DK. Satisfaction, commitment, and psychological well-being among HMO physicians. West J Med 2001;174(1):13-8. "[C C ross. $\overline{R e f}]_{1}$

27. Spickard A Jr, Gabbe SG, Christensen JF. Mid-career burnout in generalist and specialist physicians. JAMA 2002;288(12):1447-50. [C [CrossReef $]_{1}$

28. Leigh JP, Tancredi DJ, Kravitz RL. Physician career satisfaction within specialties. BMC Health Ser Res 2009;9:166. [Cross Ref $]_{1}^{\prime}$

29. Shugerman R, Linzer M, Nelson K, Douglas J, Williams R, Konrad R; Career Satisfaction Study Group. Pediatric generalists and subspecialists: deter-

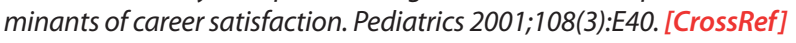

30. Dyrbye LN, Varkey P, Boone SL, Satele DV, Sloan JA, Shanafelt TD. Physician satisfaction and burnout at different career stages. Mayo Clin Proc 2013;88(12):1358-67. ['Cross Ref $]_{1}$

31. Weiss D, Dawis RV, England GW, Lofquist LH. Manual for the Minnesota Satisfaction Questionnaire Minneapolis, MN: University of Minnesota Industrial relations Center. 1967. [CrossRef]

32. Saygun $M$, ÇakmakA, KöseSK. Kırıkkaleilinde üçfarklı hastanedeçalışan hekimlerin mesleki iş doyumu. Turk Klin J Med Sci 2004;24(3):219-29. [CrossRef] 